\title{
Pengaruh Aplikasi Kelas Bk (Bimbingan Konseling) terhadap Peningkatan Pengetahuan Remajatentang HIV-AIDS di Wilayah Kerja Puskesmas Talang Banjar Kota Jambi
}

\author{
Lismawati*, Septiwiyarsih \\ Universitas Adiwangsa Jambi \\ *Correspondence email: lismawati101030@gmail.com
}

\begin{abstract}
Abstrak. Menurut World Health Organization (WHO) dilaporkan bahwa pada tahun 2011 terdapat 3,5 juta orang di Asia Tenggara hidup dengan HIV/AIDS. Trend kematian yang disebabkan oleh AIDS antara tahun 2001 sampai 2010 berbeda disetiap bagian Negara. Di Eropa Timur dan Asia Tengah sejumlah orang meninggal karena AIDS meningkat dari 7.800 menjadi 90.000, di Timur Tengah dan Afrika Utara meningkat dari 22.000 menjadi 35.000, di Asia Timur juga meningkat dari 24.000 menjadi 56.000. Menurut WHO, dari 430.000 anak yang baru lahir terinfeksi HIV pada tahun 2008, lebih dari 90\% dari mereka terinfeksi melalui penularan dari ibu ke anak. Tujuan dalam penelitian ini adalah untuk mengetahui pengaruh aplikasi kelas BK (Bimbingan Konseling) terhadap peningkatan pengetahuan remaja tentang HIV-AID. Metode penelitian menggunakan Desain penelitian pre experimental dengan rancangan one group pretest posttest design dimana rancangan ini tanpa menggunakan kelompok kontrol dan dilakukan observasi pertama (pretest) yang memungkinkan peneliti dapat menguji perubahan-perubahan yang terjadi setelah adanya eksperimen. Penelitian ini dilakukan dari tanggal 12 Agustus - 12 September,dengan sampel sebanyak 30 responden, dalam penelitian ini Data penelitian dianalisis secara univariat dan bivariat melalui uji t test dengan $\alpha=0,05$. Hasil penelitian pada analisis univariat menunjukan rata-rata pengetahuan pretest 4,53 , sedangkan rata-rata pengetahuan posttest 11,87 , dan pada analisis bivariat didapatkan p-value 0,001 sehingga dapat dismpulkan terdapat pengaruh Aplikasi Kelas BK (Bimbingn Konseling) Terhadap Peningkatan Pengetahuan Remaja Tentang HIV-AID di wilayah Kerja Puskesmas Talang Banjar Kota Jambi sebelum dan sesudah diberikan Aplikasi Kelas BK.
\end{abstract}

Kata kunci: Bimbingan Konseling; pengetahuan; HIV-AIDS

\begin{abstract}
Based on World Health Organization (WHO), in 2011 there are 3,5 million people with HIV/AIDS in Southeast Asia. The trend of death caused by AIDS between 2001 and 2010 are different in every country side. In eastern Europe and central Asia, the number of people died from AIDS increased from 7.800 to 90.000, in Middle East and the North Africa increased from 22.000 to 35.000, in East Asia also increased from 24.000 to 56.000. According to WHO, 430.000 newborn child infected with $H I V$, in 2008, more than 90\% infected by mother to child transmission. The purpose of this research is to determine the effect of the CG (Counseling guidance) class application to increasing in adolescent knowledge about HIV-AID. This research using pre experimental research design method with one group pretest posttest project, this design used without using any control group and made the first observation (pretest) which allows researchers to test the changes that occur on the experiment. This study was conducted from 12 August - 12 September, with 30 respondent as a sample, the research data ware univariately and bivariately analysis through the $t$ test with $a=0.05$. The result of univariate analyzed shows 4.53 are the average pretest knowledge, while 11.87 are the average posttest knowledge, on the other way by bivariate analysis obtained 0.001 p-value, so it can be concluded that CG (Counseling guidance) class application affect on improving adolescent knowledge about HIV-AID in Puskesmas Talang Banjar before and after given CG class Application.Keyword:
\end{abstract}

Keywords: Counseling guidance; knowledge; HIV-AIDS

\section{PENDAHULUAN}

Menurut World Health Organization (WHO) dilaporkan bahwa pada tahun 2011 terdapat 3,5 juta orang di Asia Tenggara hidup dengan HIV/AIDS. Beberapa Negara seperti Myanmar, Nepal dan Thailand menunjukkan Tren penurunan untuk infeksi baru HIV, hal ini dihubungkan salah satunya dengan diterapkannya program pencegahan HIV/AIDS melalui program Condom use 100 persen (CUP). Trend kematian yang disebabkan oleh AIDS antara tahun 2001 sampai 2010 berbeda disetiap bagian Negara. Di Eropa Timur dan Asia Tengah sejumlah orang meninggal karena AIDS meningkat dari 7.800 menjadi 90.000, di Timur Tengah dan Afrika Utara meningkat dari 22.000 menjadi 35.000, di Asia Timur juga meningkat dari 24.000 menjadi 56.000. Menurut WHO, dari 430.000 anak yang baru lahir terinfeksi HIV pada tahun 2008, lebih dari $90 \%$ dari mereka terinfeksi melalui penularan dari ibu ke anak (Najmah, 2016).

Salah satu upaya yang dapat dilakukan untuk pencegahan HIV/AIDS adalah penyuluhan kesehatan. Penyuluhan mengenai promosi hidup sehat, pendidikan sampai kepada cara menggunakan alat pencegahan yang efektif dikemas sesuai dengan sasaran upaya pencegahan HIV/AIDS pada perilaku berisiko suatu kelompok masyarakat (Kunoli, 2012)

Indonesia sudah menjadi negara urutan ke-5 di Asia paling berisiko HIV - AIDS, sehingga tidak bisa 
Lismawati dan Septiwiyarsih, Pengaruh Aplikasi Kelas Bk (Bimbingan Konseling) terhadap Peningkatan Pengetahuan Remajatentang HIV-AIDS di Wilayah Kerja Puskesmas Talang Banjar Kota Jambi

dihindari lagi bagi Inodesia untuk menerapkan kesepakatan tingkat International yang diikuti kebijakan Nasional. Kasus HIV/AIDS di Indonesia per September 2014 diketahui jumlah HIV/AIDS yang dilaporkan sebanyak 22.869 kasus. Secara komulatif HIV/AIDS sejak pertama kali ditemukan di Indonesia pada 1 April 1987 sampai dengan 30 September 2014 ditemukan sebanyak 150.296 kasus HIV, 55.799 kasus AIDS dan terdapat 9.796 kematian. Jika dilihat berdasarkan jenis kelamin terdapat 30.000 kasus AIDS pada laki - laki , 16.149 kasus AIDS pada perempuan dan sebanyak 9.649 kasus tidak diketahui. Jumlah komulatif kasus menurut faktor resiko terbesar terdapat pada heteroseksual sebanyak 34.305 kasus dan jika dilihat berdasarkan komulatif golongan umur yang paling banyak 20-29 tahun sebanyak 18.352 kasus (Kemenkes RI, 2014).

\section{METODE}

Metode penelitian menggunakan Desain penelitian pre experimental dengan rancangan one group pretest posttest design dimana rancangan ini tanpa menggunakan kelompok kontrol dan dilakukan observasi pertama (pretest) yang memungkinkan peneliti dapat menguji perubahan-perubahan yang terjadi setelah adanya eksperimen (Notoatmodjo, 2010). Desain penelitian dipilih untuk melihat Pengaruh Aplikasi Kelas BK (Bimbingan Konseling) terhadap peningkatan pengetahuan remaja tentang HIV-AIDS di wilayah Kerja Puskesmas Talang Banjar Talang Banjar Kota Jambi. Populasi penelitian ini adalah seluruh remaja di dilayah kerja Puskesmas Talang Banjar Kota Jambi, Sampel dalam penelitian ini adalah 30 responden. Teknik pengambilan sampel dalam penelitian ini dilakukan dengan teknik consecutive sampling penelitian ini dilakukan pada responden dari tanggal 12 Agustus - 12 September. Pengumpulan data dilakukan secara langsung dan menggunakan aplikasi kelas BK. Hasil penelitian di analisis secara univariat untuk mengetahui rata-rata pengetahuan pretest dan rata-rata pengetahuan posttest, dan analisis bivariat untuk mengetahui Pengaruh Aplikasi Kelas BK (Bimbingan Konseling) terhadap peningkatan pengetahuan remaja tentang HIV-AIDS di wilayah Kerja Puskesmas Talang Banjar Talang Banjar Kota Jambi.

\section{HASIL DAN PEMBAHASAN \\ Karakteristik Responden}

Berdasarkan hasil penelitian maka didapatkan distribusi umur responden sebagai berikut:

Tabel 1. Karakteristik responden

\begin{tabular}{lcc}
\hline Karakteristik & Jumlah & Persentase \\
\hline Umur & & \\
Remaja awal (10-14) & 5 & 16,7 \\
Remaja tengah (15-19) & 16 & 53,3 \\
Remaja akhir (20-24) & 9 & 30
\end{tabular}

Jenis kelamin

\begin{tabular}{lll} 
Perempuan & 19 & 63,3 \\
Laki-laki & 11 & 36,7 \\
\hline
\end{tabular}

Dari Tabel 1. yang menunjukkan bahwa sebagian besar berada di katagori remaja tengah (15-19) tahun sebanyak 16 responden $(53,3 \%)$, remaja akhir (20-24) tahun sebanyak 9 responden $(30 \%)$ dan remaja awal (10-14) tahun sebanyak 5 responden (16,7\%) Sedangkan berdasakan distribusi jenis kelamin responden, menunjukkan bahwa 19 responden berjenis kelamin perempuan $(63,3 \%)$ dan 11 responden berjenis kelamin laki-laki $(36,7 \%)$.

\section{Pengaruh Aplikasi Kelas BK (Bimbingn Konselinga) Terhadap Peningkatan Pengetahuan Remaja Tentang HIV-AID Sebelum dan sesudah Intervensi}

Berdasarkan hasil penelitian yang telah dilakukan terhadap 30 responden didapatkan hasil uji paired sample t-test untuk mengetahui pengaruh perbedaan pengetahuan sebelum dan sesudah intervensi dengan Aplikasi Kelas BK sebagai berikut:

Tabel 2. Pengaruh Pengetahuan Remaja sebelum dan sesudah intervensi dengan Aplikasi Kelas BK

\begin{tabular}{ccc}
\hline Pengetahuan & Rata-rata nilai & p-value \\
\hline Pengetahuan pretest & 4.53 & \multirow{2}{*}{$0,001^{*}$} \\
Pengetahuan posttest & 11,87 & \\
\hline
\end{tabular}

*) Paired Sample t-test is significant $<0,05$

Berdasarkan hasil uji nilai mean, dapat dilihat distribusi frekuensi pengetahuan remaja sebelum diberikan Aplikasi Kelas BK (Bimbingan Konseling) terhadap peningkatan pengetahuan tentang HIV/AIDS di wilayah kerja Puskesmas Talang Banjar. memiliki nilai rata-rata sebesar 4.53, Sedangkan nilai rata-rata setelah diberikan Aplikasi Kelas BK (Bimbingan Konseling) terhadap peningkatan pengetahuan remaja tentang HIV/AIDS yaitu nilai rata-rata 11,87 , dan uji statistik dengan menggunakan uji paired sample t-test di dapatkan nilai $p$ value sebesar 0,001 artinya $\mathrm{p}$ lebih kecil dari $0,05(0,001<0,05)$, sehingga dapat disimpulkan bahwa Ha diterima dan Ho ditolak artinya Aplikasi Kelas BK (Bimbingan Konseling) berpengaruh terhadap peningkatan pengetahuan remaja tentang HIV/AIDS di wilayah kerja puskesmas Talang Banjar kota jambi.

Berdasarkan uji paired sample t-test yang dilakukan penelitian, didapatkan nilai $p$ value sebesar 0,001, hal ini menunjukkan bahwa terdapat pengaruh Aplikasi Kelas BK (Bimbingn Konseling) Terhadap Peningkatan Pengetahuan Remaja Tentang HIV-AID di wilayah Kerja Puskesmas Talang Banjar Kota Jambi sebelum dan sesudah diberikan Aplikasi Kelas BK. Adanya peningkatan pengetahuan tentang HIV/AIDS sebelum dan sesudah diberikan Aplikasi Kelas BK ini sesuai dengan penelitian Mahmudah dalam penelitian Handayani Lutfi (2017), yang mengatakan bahwa ada peningkatan nilai rata-rata responden tentang 
kesehatan reproduksi sebelum dan sesudah diberikan penyuluhan. Didukung oleh penelitian yang dilakukan Dwiyanti dalam penelitian Handayani Lutfi (2017), yang mengungkapkan bahwa terjadi peningkatan nilai rata-rata responden tentang kesehatan reproduksi sebelum dan setelah diberikan penyuluhan. Hasil perbandingan pengetahuan sebelum dan sesudah pemberian Aplikasi Kelas BK menunjukkan bahwa sebelum diberikan Aplikasi Kelas BK didapatkan ratarata pengetahuan respondem 4.53. Setelah pemberian Aplikasi Kelas BK terdapat peningkatan rata-rata pengetahuan responden menjadi 11,87 , dan selisih ratarata pengetahuan sebelum dan sesudah adalah 7,34. Adanya peningkatan pengetahuan remaja tentang HIV/AIDS sebelum dan setelah diberikan Aplikasi Kelas BK ini sesuai dengan penelitian yang sudah dilakukan dengan Mahmudah yang menyatakan bahwa terjadi peningkatan nilai rata-rata responden tentang kesehatan reproduksi sebelum dan setelah diberikan penyuluhan. Dan didukung oleh penelitian Dwiyanti yang menyatakan bahwa pengetahuan remaja putri SMA mengalami peningkatan yang baik dengan adanya pemberian pendidikan kesehatan tentang kesehatan reproduksi.

Hasil penelitian ini sejalan dengan penelitian yang dilakukan oleh Budiman (2018) dengan judul pengaruh penyuluhan kesehatan tentang HIV/AIDS menggunakan media video terhadap pengetahuan remaja siswa dan siswi Kelas X IPS di SMA Muhammadiyah 3 Kota Yogyakarta yang menunjukkan bahwa hasil analisis statistik Wilcoxon Matched Pairs Test dengan nilai $\mathrm{p}$ value $0,000<0,05$ yang artinya ada pengaruh penyuluhan kesehatan tentang HIV/AIDS menggunakan media audio terhadap pengetahuan remaja.

Penelitian ini didukung oleh penelitian Aspiawati (2018) dengan judul pengaruh pendidikan kesehatan berbasis media video animasi terhadap pengetahuan remaja tentang HIV/AIDS di SMK Negeri 2 Makassar yang menunjukkan bahwa nilai $\mathrm{p}$ value $0,000<0,05$ berarti ada pengaruh yang signifikan antara media video animasi terhadap pengetahuan remaja tentang HIV/AIDS di SMK Negeri 2 Makassar.

Penelitian ini juga didukung oleh penelitian sebelumnya Seperti penelitian yang telah dilakukan oleh Hayati Sri (2011) dengan hasil yaitu ada pengaruh positif pendidikan kesehatan terhadap pengetahuan dan sikap sehingga dapat dikatakan pendidikan kesehatan dapat meningkatakan pengetahuan tentang HIV/AIDS. Dari penelitian diatas dijelaskan bahwa adanya peningkatan pengetahuan setelah diberikan intervensi Aplikasi Kelas BK tentang HIV/AIDS.

Faktor yang menyebabkan remaja sangat rentang terkena penularan HIV/AIDS dikarenakan remaja selalu ingin mengetahai hal-hal yang baru dalam rangka pencarian jati diri. Hal tersebut merupakan ciri-ciri remaja pada umumnya, mereka ingin mengetahui banyak hal yang hanya dapat dipuaskan dan diwujudkan melalui pengalaman mereka sendiri. Remaja ingin mencoba hal yang baru diketahuinya seperti, menggunakan narkoba, melakukan seks bebas diluar nikah, berganti-ganti pasangan, dan ditambah lagi mudahnya mendapatkan barang-barang yang berbau pornografi. Maka tidak heran jika remaja mempunyai kecendrungan untuk mengadopsi informasi yang diterima dari teman-temannya, tanpa mengetahui pasti informasi yang didaptkan dari temannya tersebut, dalam hal ini dapat berhubungan dengan seks bebas dan narkoba, yang menimbulkan rasa penasaran dan pertanyaan mulai bermunculan dalam diri remaja. Untuk menjawab pertanyan-pertanyaan tersebut maka mereka cendrung melakukan hubungan seks bebas dan narkoba. Pengaruh media televisi pun dapat menjadi pengaruh untuk melakukan seks bebas dan narkoba (Niniek Lely Pratiwi. 2011). Jelas hal ini akan mengakibatkan peningkatan penyakit menular seksual dan kecendrungan untuk meningkatkan penularan HIV/AIDS (Niasari Ayuningsih 2014).

Salah satu upaya yang dapat dilakukan untuk pencegahan HIV/AIDS adalah penyuluhan kesehatan. Penyuluhan mengenai promosi hidup sehat, pendidikan sampai kepada cara menggunakan alat pencegahan yang efektif dikemas sesuai dengan sasaran upaya pencegahan HIV/AIDS pada perilaku berisiko suatu kelompok masyarakat (Kunoli, 2012).

Pendidikan kesehatan merupakan suatu proses belajar pada diri individu, kelompok atau masyarakat, dari tidak tahu tentang nilai-nilai kesehatan menjadi tahu, dari tidak mampu mengatasi masalah kesehatan menjadi mampu mengatasi masalah kesehatan, dengan demikian pendidikan kesehatan merupakan usaha atau kegiatan membantu individu, kelompok, masyarakat untuk meningkatakan kemampuan baik pengetahuan maupun keterampilan untuk mencapai hidup sehat yang optimal. Hal ini sejalan dengan pendapat Notoatmodjo (2011) yang menyatakan bahwa pendidikan kesehatan merupakan suatu kegiatan untuk memberikan atau meningkatkan pengetahuan masyarakat dalam memelihara dan meningkatkan kesehatan.

Selain itu terdapat faktor-faktor yang mempengaruhi nilai pengetahuan menurut Notoatdmodjo (2011) dalam Wawan dan Dewi (2010) antara lain materi atau hal yang dipelajari dapat menentukan proses atau hasil belajar, lingkungan seperti kondisi tempat belajar dan lingkungan sosial yang mendukung, instrumen seperti media dan metode belajar yang digunakan dirancang sedemikan rupa sehingga sesuai dengan materi dan subyek belajar serta individu dalam kondisi fisiologi dan psikologi yang baik. Faktor-faktor tersebut diharapkan dapat menambah pengetahuan remaja tentang HIV/AIDS sehingga hubungan seks pranikah yang dapat menyebabkan HIV/AIDS dapat dihindari.

Menurut peneliti sendiri terkait penelitian yang sudah dilakukan, sebelum diberikan pendidikan 
Lismawati dan Septiwiyarsih, Pengaruh Aplikasi Kelas Bk (Bimbingan Konseling) terhadap Peningkatan Pengetahuan Remajatentang HIV-AIDS di Wilayah Kerja Puskesmas Talang Banjar Kota Jambi

kesehatan tentang HIV/AIDS, sebagian besar remaja belum mengetahui apa itu HIV/AIDS dan bagaimana penularannya, maka remaja diharapkan bisa menjadi acuan dan pedoman dalam meneruskan pembangunan, sehingga, sangatlah penting untuk memberikan pemahaman dan pengetahuan yang benar, termasuk pengetahuan tentang HIV/AIDS. Pengetahuan HIV/AIDS menurut Riskesdas (2010) masih terbatas tentang penularan dan pengetahuan tentang HIV/AIDS. Diantara semua remaja yang saya jadikan sebagai responden hanya 2 orang yang pernah diberikan penyuluhan tentang HIV/AIDS, Kurangnya informasi tentang bahaya HIV/AIDS dapat mengakibatkan terjadinya peningkatan penularan HIV/AIDS. Oleh karena itu, sangat mengharapkan agar informasi tentang HIV/AIDS dapat ditingkatkan lagi guna untuk mencegah terjadinya penularan HIV/AIDS khususnya pada remaja.

Pada era komunikasi informasi, media tidak dapat ditinggalkan dan sangat berperan penting dalam keberhasilan penyampaian informasi. Media akan membantu masyarakat umum dan remaja khususnya mengerti tentang informasi yang kita sampaikan. Selain itu, media juga dapat membantu dalam mengatasi banyak hambatan dalam pe- mahaman misalnya jika siswa tidak memahami tentang sesuatu dengan melihat media yang digunakan siswa tersebut akan lebih mudah memahami dan mengerti. Oleh karena itu, media harus dibuat semenarik mungkin agar siswa dapat mengerti tentang informasi yang disampaikan.

Aplikasi Kelas BK (Bimbingan Konseling) yang dimaksud dalam penelitian ini adalah memberikan informasi tentang HIV/AIDS sebagai bentuk mengedukasi remaja dalam rangka meningkatkan pengetahuannya, selain itu dalam aplikasi ini juga disediakan kolom konseling terjadwal yang mana responden dalam penelitian ini dapat berkonsultasi langsung dengan konselor terkait tentang HIV/AIDS. Hal ini menjadi sosusi bagi remaja dalam memecahkan masalah terkait hal tersebut, seringkali ditemui remaja yang enggan untuk berkonsultasi secara langsung, dikarenakan malu dan masih tabu untuk datang pada petugas kesehatan, namun melalui aplikasi ini remaja dapat berkonsultasi tampa harus tatap muka secara langsung, diharapkan dengan adanya aplikasi ini dapat membantu meningkatkan pengetahuan remaja tentang HIV/AIDS dan sebagai wadah dalam mengatasi masalah maaupun mencari solusi.

\section{SIMPULAN}

Dari hasil penelitian dapat di simpulkan terdapat pengaruh Aplikasi Kelas BK dengan nilai p-value $<0,05$ sebelum dan sesudah diberikan Aplikasi Kelas BK Dari hasil penelitian ini diharapkan menjadi masukan dalam melakukan kegiatan penyuluhan dan konseling kepada remaja tentang HIV/AIDS untuk menambah pemahaman dan pengetahuan remaja yang dapat berpengaruh terhadap kesehatan reproduksi remaja itu sendiri, bekerjasama dengan sekolah dan kelurahan dalam memberikan edukasi tentang HIV/AIDS dalam rangka meningkatkan pengetahuan remaja

\section{DAFTAR PUSTAKA}

Aspiawati, 2018. Pengaruh pendidikan kesehatan berbasis media video animasi terhadap pengetahuan remaja tentang HIV/AIDS di SMK Negeri 2 Makassar.

Ayuningsih Niasari, dkk. 2014. Pengaruh Penyuluhan Tentang HIV/AIDS terhadap Pengetahuan dan Sikap Siswa di SMA Negeri 1 Manado. Program Studi Ilmu Keperawatan Fakultas Kedokteran Universitas Sam Ratulangi Manado

Budiman, Muhammad Alghifari. 2018. Pengaruh penyuluhan kesehatan tentang HIV/AIDS menggunakan media video terhadap pengetahuan remaja siswa dan siswi Kelas X IPS di SMA Muhammadiyah 3 Kota Yogyakarta.

Handayani Lutfi, 2017. Pengeruh Pendidikan Kesehatan dengan Media Video terhadap Pengetahuan tentang Pencegahan HIV/AIDS di SMA Negeri 1 parigi Kabupaten Pangandara. Program Studi bidan Pendidik Jenjang Diploma IV Fakultas Ilmu Kesehatan Universitas „Aisyiyah Yogyakarta

Hayati Sri. dkk, 2011 Pengaruh Penyuluhan Kesehatan Terhadap Pengetahuan Remaja Tentang HIV/AIDS Di Kabupaten Bandung

Kemenkes RI, 2014. Pedoman Nasional Penanganan Infeksi Menular Seksual :2 Jakarta

Riskesdas, 2010. Riset Kesehatan Dasar. Jakarta : Kemenkes

Najmah, 2016.Epidemiologi Penyakit Menular :126 Penerbit Trans Info Media : Jakarta

Niniek Lely Pratiwi. 2011. Hubungan Karakteristik Remaja terkait Risiko Penularan HIV/ AIDS dan Perilaku Seks Tidak Aman di Indonesia. Fakultas Kesehatan Masyarakat Universitas Airlangga.

Kunoli, Firdaus. J. 2012. Pengantar Epidemiologi Penyakit Menular Untuk Mahasiswa Kesehatan Masyarakat. Jakarta : TIM

Kemenkes RI, 2014. Infodatin : Situasi dan Analisis HIV/AIDS. www.depkes.go.id

Notoatmodjo, 2010 Metodologi Penelitian Kesehatan :87 PT. Rineka Cipta : Jakarta

Notoatmodjo, 2011 Promosi Kesehatan, Teori dan Aplikasi:24 PT. Rineka Cipta: Jakarta

Wawan dan Dewi. 2010. Teori Pengukuran Pengetahuan, Sikap dan Perilaku Manusia. Jakarta: Nuha Medika

World Health Organization. The World Medicine Situation 2011 3ed. Rational Use of Medicine. Geneva, 2011. 